\title{
Osmanlı'dan Cumhuriyet'e Çalışma Hayatının Uzmanlaşma Süreci ve Sovyetler Birliği'nin Etkisi
}

\author{
Önder Deniz* \\ Uşak Üniversitesi İletişim Fakültesi \\ orcid.org/0000-0003-4583-0713
}

\section{$\ddot{O} z$}

Osmanlı Devleti'nde sanayileşme ile teknik eğitim çalışmaları, neredeyse ayn dönemde başlamıştır. Üretimin ana unsurunu oluşturan işgücü, sanayi devriminin ardından büyük bir değişim geçirmiştir. Fabrikaya dayal üretim insan emeğini, sadece fiziksel kuvvet olmaktan çıkarıp belli tecrübelerin ve eğitimlerin sonucunda oluşan vasıfl işgücüne dönüştürmüş̧tür. Bu dönüşümü çok iyi etüt eden Osmanlı iktisadi yapısına yön verenler, teknik eğitim konusunda birçok girişime imza atmışlardır. Teknik eğitim veren okullar açılmış, yurt dışına eğitim için öğrenci gönderilmiştir. Girişimler olumlu olmasına karşın, fabrikaya dayalı işletmelerin azlı̆̆ından dolayı Anadolu topraklarında yeteri düzeyde vasıflı işgücü oluşamamıştır. Teknik eğitime yönelik çalışmalar, Türkiye Cumhuriyet'inin kuruşundan sonrada devam etmiş, fakat yine aynı nedenlerden dolayı başarıya ulaşamamıştır. Devletin iktisadi hayata fabrika kurarak aktif işveren olduğu 30'lu yıllar ve sonrası teknik eğitim çalışmaları, çalışmaları çok farklı bir boyut kazanmıştır. Avrupa'da mensucat üretimi ile başlayan sanayileşme süreci, neredeyse 200 yıl sonra Türk topraklarında devlet eliyle yeniden başlatılmıştır. Sooyet Rusya ile iktisadi alandaki ilişkiler,

Gönderilme Tarihi 02.09.2019

$\underline{\text { Kabul Tarihi }}$ 02.09.2019

Türkiye'nin sanayileşme sürecinin önünü açmıştır. Sovyet-Türk ortaklğ̆ sonucunda farkh bölgelere açılan fabrikalar, sanayi şehirlerinin doğmasına, dış ticaret açı̆̆ının ortadan kalmasına ve iktisadi büyümeye neden olmuştur. Açlan her fabrika ayrica üretimin dışında teknik okul özelliği taşımıştır. Fabrikaları işleten idareciler, vasıflı işgücü alıp kolaya kaçmak yerine zoru seçmiş, vasıfsız işgücünü eğiterek, üretime dâhil etmişlerdir. İş ortamında eğitilen her işçi, daha sonraki yıllarda Türkiye'nin sanayi alt yapısın oluşturmuş̧tur. Yüzyıllık vasıflı işgücü yetiştirme çabaları böylece gerçek anlamda başarıya ulaşmıştır.

Anahtar Kelimeler: Osmanlı Devleti'nde Teknik Eğitim, Osmanlı İktisadi Yapısı, Devletçilik Politikası, Türkiye- Sovyet Rusya İlişkileri, Türkiye'nin İktisadi Yapısı

\section{The Process of Specialisation in Work Life and the Russian Affect from Ottoman Times to Turkish Republic}

\begin{abstract}
In Ottoman Empire, the industrialization and the technical training studies almost started in the same period. The work power which forms the main part of production changed a lot after the industrial revolution. The production based on factorization not only took out human power from only being physical power but also transformed it into the qualified labour which was the result of definite experiences and trainings. The executives who studied this transformation in detail signed the many entrepreneurships on technical training. The technical schools were opened and some students were sent abroad for training. Though these attempts were positive, the lack of businesses based on factorization led less qualified labour. The studies related to the technical training went on after the foundation of Turkish Republic but for the same reasons they couldn't achieve the success. By opening factories in the financial life, the state was an active employer in 1930 s and after then technical training studies transformed into a different dimension. The industrialization process in Europe which started with textile production was inaugurated by the state in Turkey almost 200 years later. The financial relationships with Soviet Russia opened the
\end{abstract}

*Yazışma adresi. Email: onder.deniz@usak.edu.tr 
gate way of industrialisation in Turkey. The opening factories in different regions as a result of Soviet-Turkish partnership led the born of industrialised cities, extinction of foreign trade deficit and financial growing. Every opening factory had also a technical school feature. The executives of factories did not choose the skilled labourers which was the easiest way but they chose the hardest way instead in which they trained the untrained labourers and incorporated them in production. Every trained labourer in workplace, later turned into the industrial infrastructure of Turkish industry. Therefore, the struggles of raising skilled labourers for a century succeeded in the real meaning.

Keywords: Technical Training in Ottoman Empire, Financial Structure of Ottoman Empire, State Politics, Turkey-Soviet Russia relationships, The financial structure of Turkey.

\section{Giriş}

XVIII. yüzyılın sonlarına doğru Osmanlı Devleti'nde sanayi mallarına yönelik talebin artması, iktisadi politikaların farklı bir yapıya dönüşmesine neden olmuştur ${ }^{1}$. Avrupa devletleri ile yapılan ikili ticaret anlaşmalarında yer alan maddeler, sanayi ürünlerinin ülkeye rahat girmesini sağlamış ve bunun sonucu olarak ithalat artmıştır ${ }^{2}$. İthal ürünler yönelik tüketimin artması ayrıca geleneksel ürünlere talebin azalmasına neden olmuştur ${ }^{3}$. Geleneksel yöntemlerle üretiminin yapıldığı zanaat işletmeleri, yabancı tüccarlar ile rekabet edemeyecek duruma gelmiş ve birçoğunun gelirlerinde önemli düşüşler yaşanmıştır ${ }^{4}$. Ticaret anlaşmaları, kapitülasyonların etkisi ile ticari imtiyaz haline gelmesi, Osmanlı topraklarını, yabancı sermaye için iyi bir pazar haline getirmiştir. Dış ticaret dengesi bozmuş ve cari acık, iktisadi yapının en büyük sorunu haline gelmiştir. Cari açığın finansmanı için devletin, 1854 yılı ve sonrası borçlanmaya gitmesi, iktisadi yapıya daha büyük zararlar vermiştir ${ }^{5}$.

Osmanlı aydınları ve ülkeyi yöneten kadrolar, XIX. yüzyıl sanayileşmenin önemini daha fazla dile getirmeye başlamışlardır'6. Katma değeri yüksek malları üretimine yönelik sanayileşme politikaları geçte olsa başlamıştır. İktisat politikaları doğrultusunda ilk defa 1863 yılında Sultanahmet'te uluslararası sanayi fuarları düzenlenmiştir7. Ayrıca vasıflı iş gücü yetiştirmek üzere 1864 yılından itibaren farklı vilayetlerde pek çok Sanayi Mektepleri kurulmuştur ${ }^{8}$. Avrupa şehirlerine mesleki

\footnotetext{
${ }^{1}$ Şevket Pamuk, Osmanlı Ekonomisinde Bă̆ımlılık ve Büyüme, Tarih Vakfı Yurt Yayınları, Ankara, 1994, s.28.

2 İsmail Hakkı Uzunçarşılı, Osmanlı Tarihi, Cilt 4, TTK, Ankara, 1959, s.568.

${ }^{3}$ Nafız Öztürk, “XIX. Yüzyılda Osmanlı İmparatorluğu'nda Sanayileşme ve 1827'de Kurulan Vakıf İplik Fabrikası", Vakıflar Dergisi, Sayı 21, İstanbul, s.27.

4 Serdar Şahinkaya, “XIX. Yüzyıl Osmanlı İmparatorluğu'nun İktisadi Yapısı: Sanayicilik ve Bankacılık Üzerinde Değinmeler", Mülkiye Dergisi, Cilt XXIII, Sayı:218, 1998, s.89.

${ }^{5}$ Pamuk, a.g.e., s.143.

${ }^{6}$ Mustafa Kurt, Kemalettin Kuzucu, Baki Çakır, Kemal Demir, “19. Yüzyılda Osmanlı Sanayileşmesi Sürecinde Kurulan Devlet Fabrikaları", Bir Envanter Çalışması, Ankara Üniversitesi Osmanlı Tarihi Araştırma ve Uygulama Merkezi Dergisi, Sayı 40, Güz 2016, s.248.

7 Haluk Kanca, “XIX. Yüzyılın İkinci Yarısında Uluslararası Osmanlı Fuarı: 1863 - Sergi-i Umumi-i Osmani", Muhasebe ve Finans Tarihi Araştırmaları Dergisi, sayı:5, 2013, s.163.

${ }^{8}$ Adnan Giz, "İstanbul'da İlk Sanayi Mektebinin Kuruluşu”, İstanbul Sanayi Odası Dergisi, Sayı:35, İstanbul, 1969 , s.20.
} 
eğitim için öğrenciler gönderilmiştir9 1868 yılında Islah-ı Sanayi Komisyonu kuruluşmuş ve yerli sanayinin canlandırılması yönünde çalışmalara başlanmıştır ${ }^{10}$.

1877-78 Osmanl1-Rus harbi sonrası alınan borçlar devlet hazinesinin ödenemeyeceği düzeye gelmiştir. 1881 yılında borçların ödemesine yönelik kurulan Düyûn-1 Umûmiye, devlet gelirlerinin yatırımlardan daha çok borç ödenmesine neden olmuştur ${ }^{11}$. Sanayileşmeye yönelik iktisat politikaları bu gibi nedenlerden dolayı, yüzyılın sonunda başarısızlıklara uğramıştır. Yüzyılın sonunda sanayi verilerine bakıldığında üretim unsurlarının yeterince aktif olarak kullanılmadığı görülmektedir. 1897 yılında yapılan sanayi istatistiğine göre; 23.837 adet sanayi işletmesi; Osmanlı topraklarında tespit edilmiştir. Sayı çok büyük görülmesine karşılık sayım içerisinde yer alan işletmelerin, 23.539'u un fabrikaları ve değirmenlerdir ${ }^{12}$.

XX. yüzyıla girildiğinde sermaye ve teknolojik imkânların yetersizliğinden dolayı Osmanlı iktisadi yapısı içerisinde yabancı işletmelerin hâkimiyeti iyice artmıştır. Kamu ve özel hizmetlerin yapılabilmesi için yabancı sermayenin kurduğu işletmeler, ulaşım, iletişim ve enerji gibi alanlarda hizmet vermiştir. Kâğıt üstünde işletmeler, yabancı yatırım olarak görünse de gerçekte Osmanlı iktisadi yapısına yarardan çok zarar vermiştir. İşletmelerin genellikle hizmet sektöründe yer alması, fabrikaya dayalı üretimi tercih etmemesi, iktisadi yapının dışa bağımlı kalmasına neden olmuştur ${ }^{13}$.

I. Dünya Savaşından hemen önce yabancı sermaye yatırımlarının büyük bir kısmını demiryolu inşaatı için yapılmıştır. Anadolu topraklarındaki hammaddeyi düşük maliyetlerle Avrupa fabrikalarına taşınması önemli bir yatırım olarak görülmüştür. Yabancı işletmelerin diğer yatırımları ise dış ticaret, bankacılık, sigortacılık, liman işletmeciliği, su ve gaz hizmetleri gibi sektörlerde olmuştur.

1915 sanayi istatistiklerine göre; Osmanlı Devleti sınırları içerisinde g1da, toprak, deri, ağaç, doluma, kırtasiye ve kimya sanayi kollarında faaliyet gösteren 282 müessese tespit edilmiştir ${ }^{14}$. Bu işletmeler XX. yüzyıl başlarındaki dünya sanayisi ölçeğine göre fabrikadan çok imalathanedir. Sayımlara göre şekercilik, tahin ve bisküvi imalatı başlığı altın 18 işletmenin 8 'i şeker fabrikasıdır ${ }^{15}$. Tespit edilen şeker fabrikalarının aslında şekerleme imalathaneleridir ve üretimde kullanılan şeker ithal edilmektedir. Günümüzde kullanılan şeker, ilk defa 1801 yılında Franz Karl Achard

\footnotetext{
9 Adnan Şişman, Tanzimat Dönemi'nde Fransa'ya Gönderilen Osmanlı Öğrencileri (1839-1876), Türk Tarih Kurumu Yayınları, Ankara, 2004.

${ }^{10}$ Ayrıca bakınız: Adnan Giz, "Islâh-1 Sanayi Komisyonu”, İstanbul Sanayi Odası Dergisi, Sayı:33, İstanbul, 1968.

${ }^{11}$ Şevket Pamuk, Osmanlı Ekonomisi ve Kurumları, Türkiye İş Bankası Yayınları, İstanbul, 2008, s. 146.

12 Osmanlı Devleti'nin İlk İstatistik Yıllı̆̆ı 1897, Cilt 5, Hazırlayan: Tevfik Gürhan, Devlet İstatistik Enstitüsü Yayınları, Ankara, 1997, s.262.

${ }^{13}$ Jacques Thobie, “Osmanlı Devletinde Yabancı Sermaye”, Tanzimat'tan Cumhuriyet'e Türkiye Ansiklopedisi, Cilt 3, İletişim Yayınları İstanbul, 1985, s.724.

14 Osmanlı Sanayi 1913,1915 Yılları Arası, Cilt 4, Hazırlayan: A. Gündüz Ökçün, Devlet İstatistik Enstitüsü Yayınları, Ankara, 1997, s. 14.

15 A.g.e.,s.51.
} 
tarafından Prusya'da kurulan fabrikada kimyasal yollarla üretilmiştir ${ }^{16}$. Osmanlı Devletinde ise birçok defa şeker fabrikası kurulmak istenmesine rağmen somut bir adım atılamamıştır ${ }^{17}$. Osmanlı sanayisi içerisinde bu gibi örnekler birçok üretim alanında karşımıza çıkmaktadır. İleri teknoloji unsurlarının üretimde kullanılamaması yüzünden fabrikaya dayalı üretim geçilememiştir.

\section{Osmanlı Devleti'nde Uzman İşgücü}

Osmanlı çalışma hayatı, fabrikaya dayalı üretimin oluşmamasının etkilediği alanlardan biride çalışma hayatı olmuştur. XIX. yüzyılla kadar tarım dışı çalışma hayatının büyük bir kısmını oluşturan zanaat işletmelerinde iş gücü çok farklı bir yapıda olmuştur. Sanayi sektöründen farklı olarak zanaat işletmeleri uzman işgücü yerine uzmanlaşmamış iş gücü talep etmiştir ${ }^{18}$. Bireyin uzmanlaşması, üretime aktif katılımı ile yapılması, sanayinin ihtiyaç duyduğu vasıflı işgücü talebini karşılamadan uzak bir yapıda olmuştur. Fabrikaya dayalı üretim, XIX. yüzyılın başlarından itibaren vasıflı iş gücü talebinde büyük artışlar yaşanmasına neden olmuştur ${ }^{19}$. Vasıf gerekmeyen üretim anlayışı, teknolojinin gelişmesiyle ortadan tamamen kalkmıştır.

Osmanlı'da yabancı mallara karşı duyulan talebe karşı Islâh-ı Sanayi Komisyon kurulmuş ve güçlü sanayi kuruluşları kurabilmek için çalışmalarına başlamıştır. ${ }^{20} \mathrm{Bu}$ komisyonun çalışmaları içinde sanayinin ihtiyaç duyduğu kalifiye eleman yetiştirmek için teknik okulların açılması da yer almıştır ${ }^{21}$. Okulların ilk yılları sanayiye kalifiye insan yetiştirmeden daha çok kimsesiz çocukların barınması ve eğitim almalarını sağlayan birer islah evi görüntüsünde olmuştur. Birçoğu uzun süre mesleki eğitim konusunda çağın gereklerini karşılayamamıştır22. Osmanlı'da teknik eğitim veren bu türden okulların XIX. yüzyılın sonlarına doğru yavaş yavaş kapanmalarına karşılık bazıları teknik eğitim konusunda çağın gerekmişlerini karşılayacak eğitimler vermek için yurt dışından eğitmenler getirmiştir ${ }^{23}$. Ayrıca okulların eğitim kalitelerinin artırılmasına yönelik yurt dışına öğrenci gönderilmiştir. Okulların eğitim kalitesinin artırılmasına yönelik çalışmalar başarılı bir şekilde Osmanlı Devleti'nin sonuna kadar devam etmiştir.

\footnotetext{
16 Olff, G., Franz Karl Achard, 1753-1821; a Contribution of the Cultural History of Sugar" Medizinische Monatsschrift 7, no. 4 (April 1953): 253-54.

17 Mehmet Karayaman, “Osmanlı Devletinde Şeker Fabrikası Kurma Teşebbüsleri”, Tarih İncelemeleri Dergisi, Cilt: 25 Sayı: 1, 2010, s.315,316.

${ }^{18}$ Bülent Çelik, "Osmanlı Lonca Sistemi İçinde Yamaklık Olgusu”, Tarih Araştırmaları Dergisi, Cilt: XXIII, , 2004, s. 63.

${ }^{19}$ Lawrence F. Katz, Robert A. Margo, “Technical Change and the Relative Demand for Skilled Labor", The United States in Historical Perspective, October 2014, s.17-20

${ }^{20}$ Hüseyin Vehbi İmamoğlu, Osmanlı Son Dönemi ve Büyük Güçler, İstanbul: Kriter Yayınevi, 2018, s. 174.

${ }^{21}$ Bayram Kodaman, "Tanzimat'tan 2. Meşrutiyete Kadar Sanayi Mektepleri”, Türkiye'nin Sosyal ve Ekonomik Tarihi (1071- 1920), Editörler: Osman Okyar, Halil İnalcık, Ankara, 1980, s. 288.

${ }_{22}$ Mehmet Ali Yıldırım, "II. Meşrutiyet Devrinde Vilayet Sanayi Mekteplerini Yeniden Yapılandırma Girişimleri: Vilâyât Sanayi Mektepleri Tertibatı", Tarih Araştırmaları Dergisi, Cilt: 31 Say1: 52, 2012, s.138,139.

${ }^{23}$ A.g.m., s.140.
} 
II. Meşruiyet ilanından sonra ülkeyi yöneten kadroların milli iktisat düşüncesi, sanayiye kalifiye insan yetiştirmek üzere yapılan çalışmaları da hızlandırmıştır. Dünya savaşının öncesinde Alman İmparatorluğu ile ilişkiler gelişmesi, eğitim alanına da yansımış ve birçok öğrenci, Alman şehirlerine sanayi eğitimi alması için gönderilmiştir24. Ayrıca İttihat ve Terakki yönetimi, hem aktif olan yabancı işletmelerde yabancı işgücünün azaltmak hem de yerli işgücünü uzmanlaştırmak için çalışmaları başlatmıştır. Bu doğrultuda 1913 tarihli Teşvik-i Sanayi Kanun-1 Muvakkatı'nın beşinci maddesi; teşvik karşıllı̆ı işletmenin işgücünün Osmanlı tebaasından sağlanmasını zorunlu kılmıştır ${ }^{25}$.

Yabancı ortaklıkla kurulmuş işletme, istediği milletten işgücünü hiçbir engele takılmadan işbaşı yaptırmakla kalmayıp bağlı bulunduğu ülkenin dilinde yazışma ve hesap kayıtları tutmuştur ${ }^{26}$. Yerli iş gücü, yabancı dil bilmediği takdirde yabanc1 işletmelerde çalışması imkansız hale gelmiştir. Bu olumsuzluğu önlemeye yönelik hesap kayıtlarının ve yazışmalarında Türkçe kullanılması için bir kanun çıkarılmıştır. Müe'essesât-1 Nâfi'a ile İmtiyâzsız Şirketler Muhâberât ve Mu'âmelâtında Türkçe İsti’mâli hakkında kânun maddelerinde, işletmelerin kayıtlarında ve yazışmalarında Türkçe yapılması için düzenlemeleri yer almıştır²7.

XVII. yüzyıldan itibaren Avrupa'da teknolojinin gelişimiyle birlikte eğitim, üretim, sermaye ve nitelikli insan faktörü önem kazanmıştır. Bu dört yapı birbirine bağlı olarak gelişmiş ve sanayi devriminin temelini oluşturmuştur. Almanya, ABD ve İngiltere gibi ülkelerde, $X X$. yüzyılın başlarında 2. Sanayi Devrimi yaşanırken teknolojik üretiminin yetersizliği, vasıfsız iş gücü, eğitim yetersizlikleri, yabancı işletmelerin yerli iş gücüne olumsuz bakışı ve çalışma hayatına yönelik sosyal politikaların oluşamaması gibi iktisadi sorunlar, Osmanlı Devleti'nin yıkılışına kadar devam etmiştir.

\section{Cumhuriyetin İlk Yıllarında Çalışma Hayatının Uzmanlaşmasına Yönelik Çalışmalar}

Kurtuluş Savaşının ve Lozan Anlaşmasının ardından büyük bir siyasi ve askeri başarı elde edilmiştir. Bu başarının baş mimarı Gazi Mustafa Kemal Paşa ise başarının ancak iktisadi kalkınma ile olacağını Cumhuriyet'in ilanından önce ve hayatı boyunca her fırsatta dile getirmiştir ${ }^{28}$. Ona göre milli iktisat politikası; ülkenin sanayileşmesinde önemi büyüktür. Çiftçi, tüccar, sanayici ve işçi bir başka değişle üretimde aktif rol oynayan unsurların milli olmaları, sanayileşmenin ana dayanağıdır. Cumhuriyetin ilanından yaklaşık sekiz ay önce İzmir'de bir İktisat Kongresi düzenlenmesinin ana dayanağı bu düşüncedir. Gazi Mustafa Kemal Paşa, İktisat Kongresinin açılış

\footnotetext{
${ }^{24}$ Zafer Toprak, "II. Meşrutiyet ve Osmanlı Sanayi”, Tanzimat'tan Cumhuriyet'e Türkiye Ansiklopedisi, s.1656,1357.

25 A. Gündüz Ökçün, “Teşvik-i Sanayi Kanun-1 Muvakkatı,1913” Ankara Üniversitesi Siyasal Bilgiler Fakültesi, Dergisi, Cilt: 30, Yayın Tarihi: 1975,s.25-26.

${ }^{26}$ Rıfat Günalan, “Tanzimat Sonrasında Osmanlı Devletinde Yabancı Şirketler Tarafından Yürütülen İş ve İşlemlerinde Türkçenin Kullanımı Meselesi", Avrasya Incelemeleri Dergisi, V/2 (2016), s.341-363.

${ }^{27}$ Düstür, Cilt.8, İstanbul Evkaf Matbaası, İstanbul, 1928, s. 775,776.

28 Atatürk'ün Söylev ve Demeçleri, I-III, Atatürk Araştırma Merkezi, Divan yayınları, Anakara, 2006.
} 
konuşmasında29; “...Bugün mevcut fabrikalarımızda ve daha çok olmasını temenni ettiğimiz fabrikalarımızda kendi amelemiz çalışmalıdır...", sözleriyle yeni kurulacak devlette, yerli işgücüne verilen önemi vurgulamıştır. Kongrede; ayrıca işçi grubunun iktisadi esaslarının 26. Maddesinde yer alan"30; "Memlekette açılacak büyün işlerin Türk erbab-ı say ve amelesine tahsisi." diğer gruplar tarafından kabul edilmesi önemli bir gelişmedir ve Gazinin açılış konuşmasını destekleyici mahiyettedir. Daha sonraki yıllarda vasıf gerektirsin veya gerektirmesin özellikle yabancı yatırımlarla kurulan işletmelerde yabancı işgücü tercihi, Isparta mebusu Hafız İbrahim (Demiralay) 3 Haziran 1926 yılında TBMM Riyaset-i Celilesine verdiği dilekçede iktisadi hayatta ne kadar sorun yarattığ1 açıkça belirtilmiştir ${ }^{31}$.

Yerli işgücünün özellikle vasıf gerektiren işlerde aktif olarak çalıştırılması yönündeki çalışmalar, 28 Mayıs 1927 Tarihli Teşviki Sanayi kanununda yer alacaktır. Kanunun 28 maddesi 32 ;

\begin{abstract}
"Bu kanunda yazll müsaade ve muafiyetlerden kısmen veya temam en istifade eden sinai müesseselerin yalnı müdür ve muhasebecileri ecnebi olabilir. Bundan maada bilumum memurin ve müstahdemin ve amelenin Türk olması meşruttur. Ancak müessesenin istemesine muktezi olup dahilde bulunamayan mütehassis memur ve ameleler ait olduklar vekâletin müsaadesi ve yerlerine Türk yetiştirilmesi şartı ile mahdut miktar ve müddetlerle ecnebi olarak istihdam olunabilirler."
\end{abstract}

Sanayi Teşvik Kanununda yürürlüğe girmesi ile birlikte, teşvikten yaralanacak Türk işgücü çalıştırması zorunlu kılınmamıştır. Ayrıca maddelerde işçinin teknik eğitimi de işverenin sorumluluğu dâhil edilmiştir. Kanunun bu gibi maddelere yer almasına rağmen yaptırım gücü olmadığından yabancı işgücü Anadolu'ya kontrolsüz bir şekilde girmiştir.

\title{
4. Sovyet Birliği İktisadi İlişkiler
}

Cumhuriyetin ilanından itibaren sanayileşme yönündeki teşvikler istenilen düzeyde olamamış ve cari acık artmaya devam etmiştir. Teşviklerden yabancı ve yerli girişimciler faydalanmış olmasına rağmen fabrikaya yönelik üretim unsurları devreye girememiştir. Ülkede farklı bir iktisat politikası belirlenmesi için çalışmalar, 1929'un Haziran ayında Ali İktisat Meclisinde, cari açığı kapatma ve fabrikalaşmaya yönelik bir rapor hazırlanmıştır ${ }^{33}$. Rapor, Aralık ayında İktisat vekilliğine bağlı bir komisyonda yeniden düzenlemeye tabi tutularak 1930 Mart ayında Vekil Şakir Bey imzası ile

\footnotetext{
${ }^{29}$ A.g.e., cilt.2, s.116.

${ }^{30}$ A. Gündüz Ökçün, Türkiye İktisat Kongresi 1923-İzmir Haberler Belgeler Yorumlar, Sevinç Matbaası, Ankara 1971, s.433.

${ }^{31} B C A$, Kurum: 30.10.0. Kutu No: 8 Dosya No: 46 Sira No: 8 Belge Tarihi: -

32 TBMM Zabit Ceridesi, Cilt 32, TBMM Matbaas1,1927, s.618.

33 Yahya S. Tezel, Cumhuriyet Dönemi İktisadi Tarihi (1923-1950), Tarih Vakfı Yurt yayınları, İstanbul, 2002, s.293.
} 
Başvekâlete sunulmuştur"34. 22 Mayıs 1930 tarihinde 66 Maddelik "Milli İktisat Programı" kamuoyuna duyurulmuştur ${ }^{35}$.

Anadolu'nun yeraltı ve yerüstü zenginliklerine göre hazırlanan iktisat politikasının başarılı olabilmesi için hem paraya hem de teknolojik desteğe ihtiyaç duyulmuştur. Bu doğrultuda Milli Mücadele döneminden itibaren ilişkilerin iyi tutulduğu Sovyet Rusya ile iktisadi yakınlaşmaya gidilmiştir. 26 Ekim 1931 tarihinde Sovyetler Birliği Dışişleri Halk Komiseri Maksim Maksimoviç Litvinov, Türkiye'ye ziyareti tam anlamıyla karşıla şölenine dönüşmüştür ${ }^{36}$. Litvinov ile İnönü arasındaki Ankara'daki görüşmeler, iktisadi alandaki Türk-Sovyet ortaklığını başlatmıştır ${ }^{37}$.

Litvinov Sovyet Rusya'ya dönmesinin ardından Başbakan İnönü'nün 24 Nisan10 Mayıs 1932 tarihleri arası Sovyet Rusya'da ziyareti, ilişkileri tamamen iktisadi boyuta taşımıştır. Başbakanın Moskova ziyaretine Türkiye'den iktisadi alanda birçok önemli isim katılmıştır. Dışişleri Bakanı Tevfik Rüştü Bey başta olmak üzere birçok fabrikanın müdürü ve iktisat konusunda bilgisi olan milletvekilleri, bürokrat Moskova heyetinin içinde yer almıştır ${ }^{38}$. Heyet, Sovyet Rusya'da fabrikaları ziyaret etmiş ve incelemelerde bulunuştur ${ }^{39}$. Bu gezinin ardından Sovyet Rusya Hükümeti, Türkiye'ye 16 Milyon Türk Liralık mensucat makinesi, üç ufak iki büyük tank, iki kamyon bir otobüs ayrıca Mustafa Kemal ve İsmet Paşalara iki de at hediye etmiştir. Makinelerin ödemesi 20 yıllık taksitler halinde olacak ve faiz alınmayacaktır ${ }^{40}$. Anlaşma hem Sovyet Rusya'nın hem de Türkiye'nin dünyadaki siyasi ve iktisadi yerini bir anda değiştirmiştir. Bu anlaşma Avrupa ve Amerika basınına çok farklı boyutlarda yansımıştır. Daily Telegraph gazetesinin 30 Mayıs 1934 tarihli sayısında Rusya'dan Türkiye'ye Finansal yardım başlığı altındaki haberde ${ }^{41}$;

"Sovyet Rusya, Yakındoğu bölgesine borç veren gü̈çler aranasına girdi. Rusya diğer ülkelerin endüstrilerini yeniden düzenleyen bir uzman oldu.

Türkiye tarafindan sipariş edilen zaruri tekstil makinelerinin 8000000 Dolar veya Sterlin 1600000 lira kredisinin ilk teslimatı, Eylül ayında yapılacaktır. Yeni Türk fabrikalarını arasına, Rus mühendisler tarafindan özel olarak organize edilen Sovyet teknolojisi fabrikalar yerleştirilecek. Rusya, genel anlamda akut bir şekilde hissedilen siparişi hızlandırmak amacıyla Türklere toplamda 2565 tekstil makinesi vermeyi teklif etti.

Çeşitli politik değerlendirmeler, aynı zamanda Rus ve Türk endüstrisine saygll biçimde ayrılmış, geleceğin Oryantal Yakın ve Uzak Doğu tekstil bölgesine bu anlaşmanın gerisine gizlenmiştir.

\section{Gerçekte varsayılan;}

\footnotetext{
${ }^{34}$ A.g.e., s.293.

${ }^{35}$ Cumhuriyet Gazetesi, 22 May1s 1930.

${ }^{36}$ Akşam Gazetesi, 27 Ekim 1931.

37 Ulus Gazetesi, 28 Ekim 1931.

${ }^{38}$ Akşam Gazetesi, 24 Nisan 1932.

${ }^{39}$ Akşam Gazetesi, 30 Nisan 1932.

40 Akşam Gazetesi, 8 Mayıs 1932.

${ }^{41}$ BCA, Kurum: 30-10-0-0 / Muamelat Genel Müdürlüğü, Yer Bilgisi: 234 - 579 - 10, Dosya Ek: 422, Belge Tarihi: 25.06.1934. Haber Fransızcadan çevrilmiştir.
} 
Bu kredi, ucuz mal sağlayarak, başlıca gıdalar veya ticari ve endüstriyel tavizlerle on yılda ödenecektir."

Yine 8 Eylül 1935 tarihinde New York Times Gazetesinin Walter Duranty'in Sovyet-Türk İrana teşmil edildi başlığ

“...Sovyet İttihadı fil hâl Türkiye'de geniş maksatta inşaat yapmayı ve bilhassa mensucat fabrikaları inşasını taahhüt etmiş bulunmakta olup Sovyet İttihadının Türkiye ve İran inkişaflarında müsait olan coğrafi ve siyasi vasiyetinden istifade ederek gitgide büyük bir rol oynamak niyetinde olduğu aşikâr

Sovyet Hükümetinin Mustafa Kemâl Atatürk'e Yunan Harbinin en can alacak bir devresinde müteveffa Harp Komiseri Frunze'yi silâh cephane ve para ile muavenete göndermiş olmasindan beri Sooyet Rusya ile Türkiye arasında sıkı bir siyasi askeri münasebet mevcut bulunmuştur.

Sovyet Rusya ile Türkiye arasinda resmi bir ittifakın mevcudiyeti burada inkâr edilmektedir. Fakat bugün Türkiye, İran ve Sovyet İttihatları arasında icabr takdirinde müştereken hareketi istihdafeden bir Enlente Cordiale (1904'te imzalanan Ingiltere Fransa dostluk antlaşması) 'in mevcut olduğuna şüphe yoktur. Hindistan'ın bu günkü aldığı şekle güre göre bir vaziyetin pek yakın bir atide tahassür edebilmesi ihtimali Lavantin Üçler İttihadı tesmiye olunabilecek olan bu Entente'in üç azası arasınınki dostluk tezahüratına daha ziyade bir ehemmiyet vermekteyiz."

Alınan kredi İngiliz Sterlini kuru ile altı aylık taksitler ile yirmi yılda ödenecektir. Ayrıca Türkiye, Rusya'ya yün, tiftik, tütün, kuru üzüm, incir, zeytinyağı, kürk, pamuk, palamut valeks (palamut hulâsası) susam, hayvanat, zeytin, ham deri, portakal, limon gibi ürünlerde uygun fiyatlı mal temin edilecektir³.

1929 Buhranı ile liberal iktisadi yapıların çöküşü, Sovyet Rusya'nın iktisadi modelini popüler hale getirmiştir. Ayrıca Sovyet Rusya'nın Ortadoğu'da güç dengesini değiştirme isteği, sanayileşme sürecine girme isteğinde olan Türkiye'nin önünü açmıştır. Türkiye'de bir türlü gerçek anlamda başaramadığı, sanayileşme sürecini Sovyet Rusya'ya yaklaşarak başarma isteği, olumlu bir politika oluşturmuştur.

\section{Rus Uzmanların Raporlarının Türk İşgücüne Etkileri}

Sovyet Rusya ile iktisadi ilişkilerin ilk somut adımı, 12 Ağustos 1932 yılında iki iktisat Profesörü Orloff ve Kovelefski başkanlığında Rus uzmanlardan oluşturulan bir komitenin, Türkiye'ye gelerek incelemelere başlamışlardır ${ }^{44}$. Rus uzmanların bayındırlık ve iktisat bakanlıkları bünyesindeki mühendislerin eşlik etmesi kararlaştırılmıştır ${ }^{45}$. Heyet ilk olarak İstanbul, Ankara Eskişehir, İzmir, Nazilli ve Aydın'da incelemelerde bulunmuş, daha sonra aynı heyet Konya, Adana gibi vilayetlerde de incelemelerde bulunmuşlardır ${ }^{46}$. Rus ve Türk uzmanlardan oluşan

\footnotetext{
${ }^{42}$ BCA, Kurum: 30-10-0-0 / Muamelat Genel Müdürlüğü, Yer Bilgisi: 268 - 803 - 17, Dosya Ek: 440, Belge Tarihi: 11.09.1935.

${ }^{43}$ Resmi Gazete, 24.05.1934, No: 2709.

${ }^{44}$ Hâkimiyeti Milliye Gazetesi, 8 Eylül 1932.

${ }^{45}$ Akşam Gazetesi, 11 Ağustos 1932.

${ }^{46}$ Akşam Gazetesi, 7-18 Eylül 1932.
} 
heyet, incelemede bulundukları bölgelerde en üst yetkililer tarafından karşılanmış ve ağırlanmışlardır. Kurulacak fabrikaların hangi bölgeye uygun olduğuna ilişkin etütler, Türkiye'de ve Sovyet Rusya'daki laboratuvarlardaki incelemeler sonucunda oluşturulmuştur ${ }^{47}$.

Türk ve Rus uzmanların hazırladığı raporlar bir buçuk yılık etütler sonucunda şubat ayında Moskova'da hazırlanarak Mühendis Şevket Turgut Bey ile yardımcısı Fahri Hüsnü Bey'e teslim edilmiştir. Raporlarda fabrikaların planı, mimarisi, inşaat tarzı, teknik havalandırma, şofaj ve kanalizasyonu yer almıştır. Ayrıca projelerde fabrika çalışanların barınacakları binalar, sosyal tesiler ve spor alanları da raporlarda yer almıştır ${ }^{48}$. Projelerin en ilginç noktası ise fabrikaların etrafına kurulacak kasaba ve mahallelerin planları da projede yer almasıdır. Avrupa'da 18. yüzyılda fabrikalaşma ile başlayan şehirleşme olgusu Anadolu topraklarında planlı bir proje ile yapılmaya çalışılmıştır ${ }^{49}$.

Hükümet Moskova'da hazırlatılan raporların yanında Amerikalı iktisatçı Hinesin rapor hazırlatmak istenmişse de vefat etmesinden dolayı görev yine bir iktisatçı olan Dor verilmiştir. Edwin Walter Kemmerer danışmanlığı doğrultusunda Dor ve ekibi bir rapor hazırlamıştır ${ }^{50}$. Kemmerer, birçok konuda Türkiye'ye danışmanlık yapmış, dönemin önemli iktisatçıları arasında yer alması raporun önemini artırmışıır $^{51}$. Bununla birlikte Mayıs ayında Amerikalıların hazırladığı rapordan önce, hükümet Ruslar ile hazırlanan ilk sanayi planını 17 Nisan 1934 tarihinde resmen uygulamaya başlatmıştır ${ }^{52}$. Anadolu topraklarında hayvansal, bitkisel ve kimyasal hammaddenin bol ve ucuz olması planların mensucat sanayisi ağırlıklı olmasına neden olmuştur. Ayrıca açılacak fabrikaların yakın bölgelerinde demiryolu hattının bulunması da planları doğrudan etkilemiştir.

\footnotetext{
${ }^{47}$ Akşam Gazetesi, 11 Ağustos 1932.

${ }^{48}$ Akşam Gazetesi, 18 Şubat 1934.

49 17. ve 18 yüzyılda sanayileşme ile birlikte çalışma hayatında büyük değişimler yaşanmıştır. Sanayileşme bir anlamda fabrikaya dayalı üretim anlamı taşımış ve fabrikalar, çalışma hayatını yeniden şekillendirmiştir. Fabrikalar, sosyal hayatta işçi sınıfının doğmasına neden olmuş ve sanayileşmenin ana unsurunu oluşturmuştur. Şehirlerden ve köylerden insanlar, fabrikaların bulunduğu bölgelere göç etmeye başlaması yeni şehirlerin oluşmasına neden olmuşlardır.

${ }^{50}$ BCA, Kurum: 30-18-1-2 / Kararlar Daire Başkanlığı (1928- ), Yer Bilgisi: 44 - 27 - 18 Dosya Ek: 243-161, Belge Tarihi : 03.05.1934

${ }^{51}$ Paul W. Drake, " Edwin Walter Kemmerer " Encyclopedia of Latin American History and Culture, vol. 3, s. 348.

52 Tezel, a.g.e, s. 295.
} 
Tablo 1. Birinci Beş Yıllık Sanayi Planına Göre İşletmelerin İstihdam Yapıs1 ${ }^{53}$

\begin{tabular}{|l|l|l|}
\hline Fabrikanın İsmi & İşletmeye Açıldı̆̆ı Tarih & Amele Miktarı \\
\hline Bakırköy Pamuklu Fabrikası & Mayıs 1934 & 720 \\
\hline Kayseri Bez Fabrikası & Eylül 1935 & 4500 \\
\hline Ereğli Bez Fabrikası & Nisan 1937 & 1500 \\
\hline Nazilli Basma Fabrikası & Ekim 1937 & 2400 \\
\hline Malatya Bez Fabrikası & Temel Atma 1937 & 700 \\
\hline Bursa Merinos Fabrikası & Temel Atma 1935 & 800 \\
\hline İzmit Kâğıt ve Karton Fabrikası I. & 1936 & 300 \\
\hline İzmit Kâğıt ve Karton Fabrikası II. & Temel Atma 1936 & 300 \\
\hline İzmit Selüloz Fabrikası & Temel Atma 1936 & 180 \\
\hline Gemlik Suni ipek Fabrika & Temel Atma 1936 & 400 \\
\hline Karabük Demir ve Çelik Fabrikası & Temel Atma 1937 & 761 \\
\hline Zonguldak Antrasit Fabrika & 1935 & 91 \\
\hline Keçiborlu Kükürt & Mayıs 1935 & 265 \\
\hline İstanbul Cam Fabrikası & 1935 & 500 \\
\hline Isparta Gülyağı Fabrikası & Mayıs 1935 & 20 \\
\hline
\end{tabular}

Türkiye'nin ilk sanayi planının en çan alıcı noktası istihdamdır. Kurulması planlanan fabrikalar, her anlamda teknik altyapı gerektirdiğinden uzman işgücüne ihtiyaç duyulmuştur. İşletmelerde çalışacak iş gücünün eğitimi, üretime geçişin ana konularından bir olması, teknik eğitim konusundaki çalışmaları hızlandırmıştır. Teknik eğitim; işçilerin yurt dışına gönderilmesi ve yurt dışından eğitmenler getirilmesi en fazla uygulanan iki yöntemler olmuştur.

\subsection{Sovyet Rusya'ya Eğitim Amaçlı Gönderilen İşgücü}

Birinci Beş Yıllık Sanayi Planının hazırlanmasında Rus uzmanlar ile ortak çalışılması, fabrikaların kurulma ve işletilme sürecinde de aynı uzmanlara ihtiyaç duyulmasına neden olmuştur. Bununla birlikte Moskova ve Leningrad'a yapılan iktisadi ziyaretlerde artışlar yaşanmıştır. Her ziyarette ortak kanı, Rus sanayisinin Amerikan sanayisine göre daha fazla geliştiği üzerine olmuştur. Özellikle Sovyet Rusya'nın yedi sanayi altyapısından çok etkilenilmiş ve bu alanlar üzerinde eğitim yoluyla teknoloji transferi yapılmak istenmiştir ${ }^{54}$.

Teknik eğitim için bu dönemde sadece Sovyet Rusya'ya dışında İngiltere, Almanya, İsviçre gibi ülkelere de devlet desteği ile işgücü gönderilmiştir ${ }^{55}$. Sümerbank bünyesindeki işletmelerin çalışan bireylerin eğitimine doğruda Cumhurbaşkanlığ kararnamesi ile oluşu, yerli işgücünün uzmanlaşmasına verilen önemin göstergesi olmuştur. Yapılan planlara uygun bir şekilde işgücü Sovyet Rusya'ya gönderilmesine karar verilmiştir. Yurt dişına eğitime giden her birey yurda döndüğünde öğrendiği

\footnotetext{
53 Sümerbank Bülteni, Y11:3, Sayı: 9-10

${ }^{54}$ BCA, Kurum: 30-10-0-0 / Muamelat Genel Müdürlügü, Yer Bilgisi: 200 - 362 - 16 Dosya Ek: 238, Belge Tarihi:14.08.1935.

${ }_{55}$ BCA, Kurum: 30-18-1-2 / Kararlar Daire Başkanlığı (1928- ), Yer Bilgisi: 69 - 82 - 3 Dosya Ek: 257-184, Belge Tarihi: 16.10 .1936
} 
tecrübeyi ve deneyimleri iş ortaminda aktarması, özellikle mensucat üretiminde Türkiye'nin ileriki yıllarda dünyada söz sahibi olmasında etkisi büyüktür. Sovyet Rusya'ya stajyerler, başlarında Fahri Hüsnü Bey'e olacak şekilde bir yıla yakın eğitim için gönderilmişlerdir ${ }^{56}$.

Tablo 2. Sanayi Planı Çerçevesinde Yurt Dışındaki Gönderilen Personelin Eğitim Alanlar1 ${ }^{57}$

\begin{tabular}{|l|l|}
\hline Sanayi Kolu & İçeriği \\
\hline A ̆̆ır Sanayi & Madencilik, Metalurji, Enerji, Savunma, Kimya \\
\hline Hafif Sanayi & Tekstil \\
\hline Mahalli Sanayi & Küçük İmalat Ürünler \\
\hline Gıda Maddeleri Sanayisi & Şeker, Yağ v.b \\
\hline Şimendifer & Tren Rayı, Vagon ve Lokomotif imalatı \\
\hline Yollar & Asfalt ve Yol Malzemeleri \\
\hline Su Yolu Ulaşımı & Nakliye Gemisi İmalatı \\
\hline
\end{tabular}

Mensucat fabrikaların kurulması ile ilgili başarılı işlere imza atılması, diğer sanayi kollarına yönelik palanları hızlandırmıştır. Teknoloji transferinin yoğunlaştığı yılların hemen başında Sovyet Rusya ile sadece mensucat sanayisi konusunda değil, birçok sanayi alanında uzman yetiştirmek için stajyer öğrenciler gönderilmiştir ${ }^{58}$. Ayrıca fabrikanın kurulacağı bölgenin özelliklerine göre Sovyet Rusya'da hazırlanan projelere, ekipler gönderilerek Türk uzmanlara eğitimler verilmesi sağlanmıştır ${ }^{59}$. Özellikle Sovyet Rusya'ya gönderilen işgücü mensucat fabrikalarda ustabaşı olarak görevlendirilmiştir ${ }^{60}$. Eğitimlerin genel amacı her türlü kaynak yönünden zengin olan Anadolu'daki hammaddeyi yerli emek kullanarak yüksek teknoloji ürününe çevrilmesidir. İmalat sanayisi bir ülkenin dışa bağımlılı̆̆ını en aza indirmenin en kesin yolu olmaktadır ${ }^{61}$. Yerli işgücü imalat sanayisinin temelini oluşturduğundan, yurtdış1 eğitimlere ayrı bir önem vermiştir. Yeni açılan mensucat fabrikalarında yurtdışı

\footnotetext{
${ }^{56}$ Cumhuriyet Gazetesi, 6 Haziran 1933

${ }^{57}$ BCA, Kurum: 30-10-0-0 / Muamelat Genel Müdürlüğü, Yer Bilgisi: 200 - 362 - 16 Dosya Ek: 238, Belge Tarihi: 14.08 .1935$.

${ }^{58}$ BCA, Kurum: 30-18-1-2 / Kararlar Daire Başkanlığ ${ }_{1}$ (1928- ) Yer Bilgisi: 41 - 85 - 7 Dosya Ek: 112-124

Belge Tarihi: 04.12 .1933 .

${ }^{59}$ BCA, Kurum: 30-18-1-2 / Kararlar Daire Başkanlığ (1928- ) Yer Bilgisi: 47 - 58 - 19 Dosya Ek: 130-50 Belge Tarihi: 27.08.1934.

${ }^{60}$ Endüstri Dergisi, Nisan 1937, Sayı: 8, Aktaran: Büşra Bigat, Kuruluşu Ve İlk Yıllarında Nazilli Sümerbank Basma Fabrikası, Adnan Menderes Üniversitesi Sosyal Bilimler Enstitüsü Tarih Anabilim Dalı Basılmamış Yüksek Lisans Tezi, 2017, s.162.

61 Donald Quataert'ın 1993 yılında çıkardığı Ottoman Manufacturing in the Age of the Industrial Revolution kitabında Sanayi devrimi döneminde Osmanlı Devleti sınırları içerisindeki ham pamuk, boyar madde, iplik, kumaş ipek kumaş, ham ipek, halı imalat sektörü olarak belirtilmiştir. Bu ürünler aslında mensucat imalat sanayisi için hammadde ürünleridir. İngilizce Manufacturing olarak adlandırılan imalat sektörü; bir hammaddeyi veya yarı mamulü işleyerek bir sanayi ürünü haline getirmek anlamı taşımaktadır. Osmanlı Devleti sınırlarında gerçek anlamada ticarete yönelik mensucat fabrikası mevcut değildi. Anadolu topraklarındaki mensucat sanayisi gerçek anlamada Devletçilik politikalarının yoğunlaştı̆̆ 1 döneme rastlamaktadır.
} 
eğitimlere rağmen uzun süre binli sayıda yabancı işgücü çalıştırılmıştır ${ }^{62}$. Eğitimli iş gücünün ne kadar önemli olduğu sadece yabancı iş gücü sayısal fazlalığı ile değil aynı zamanca ücretler ile de görülmüştür. Sümerbank bünyesinde Polonya uyruklu uzman Jan Stanko 1032,20 Türk Lirası aylık maaş alırken ${ }^{63}$ Teknik Genel Müdür Yardımcısı Bülent Büktaş aylık 875 Türk Lirası almaktadır ${ }^{64}$. Unvana göre ücret adaletsiz olarak görülse de Sümerbank tarafından yabancı uzmanlar, üretimin ana unsuru olduğundan aylıkları yüksek tutulmuştur. Uzmanların üretim dışında ikinci görevi yerli iş gücünü üretim teknikleri açısından eğitmek olmuştur.

\subsection{Sovyet Rusya'dan Türkiye'ye Çalışmaya Gelen Uzmanlar}

Yabancı işgücünün ülkede varlığı Osmanlı'dan Cumhuriyet'in ilk yıllarına kadar büyük sorun teşkil etmiştir. Yabancı işgücü, yerli işgücünden daha fazla ücret almış ve genelde üst kademelerde istihdam edilmiştir ${ }^{65}$. Yabacı sermayeli işletmelerin çoğunlukla yabacı uzman tercih etmesi, Anadolu'nun sanayileşme sürecine büyük zarar vermiştir. Her ne kadar devlet yöneten kadrolar bu olumsuz yapıya müdahalede bulunmuşsalar da başarı sağlayamamışlardır.

Cumhuriyetin ilanının ardından tekrar imar çalışmalarına başlanması, yabancı işgücü sorunun tekrar gündeme getirmiştir. Yabancı şirketlere verilen imtiyazlar, hem kaçak hem de kaçak olmayan yollarla ülkeye çok sayıda yabancı işgücünün girmesine neden olmuştur ${ }^{66}$. Bu sorunu ortadan kaldırmak için mecliste çalışmalar 1926 yılında başlamış ve 1932 yılında çıkarılan bir kanunla sonuçlandırılmıştır. Türkiye'de Türk Vatandaşlarına Tahsis Edilen Sanat ve Hizmetler Hakkında Kanunun, yabancı işgücünü gerekli hallerde devletin yetkili kurumlarınca verilen izinle çalıştırılması sağlanmıştır"67. Kanunun üçüncü maddesinde yer alan; "Türk vatandaşlarına tahsis edilmiş olan sanat ve hizmetlerin ecnebi tebaası tarafından icrası icabında İcra Vekilleri Heyeti kararı ile menolunabilir." 30'lu yılların ikinci yarısıyla birlikte projeler dâhilinde kurulan mensucat fabrikaları ile birlikte uzman işgücü açığı ortaya çıkmıştır. Mensucat ürünlerinin ham maddesi, pamuk, iplik ve ipek, Anadolu toparlaklarında önemli bir geçim kaynağ 1 olmuştur ${ }^{68}$. Bununla birlikte sanayi devriminin getirdiği teknoloji ve makineye dayalı üretim, Osmanlı'da mensucat sektöründe çok fazla örneği olmamıştır ${ }^{69}$. Genellikle üretim, küçük imalathanelerde ve evlerin uygun bölümlerinde

\footnotetext{
62 Sümerbank Nazilli Basma Fabrikası İşçi Kayıtları Aktaran: Hulusi Doğan, Sanayinin Musikisi Nasıl Başladı Nasıl Bitti? Sümerbank Nazilli Basma Fabrikası'na Tarihsel Bir Bakış, Ege Akademik Bakış / Ege Academic Review 7 (2) 2007, s.675.

${ }^{63}$ BCA, Kurum: 030-0-0-18 Yer Bilgisi: 001-002-114 Dosya Ek 63-8 Belge Tarihi: 22.09.1947.

${ }^{64}$ BCA, Kurum: 030-0-0-18 Yer Bilgisi: 001-002-115 Dosya Ek:70-16 Belge Tarihi: 13.10.1947.

65 Taner Timur, Türk Devrim ve Sonrası, İmge Yayınları, Ankara, 2001, s.130.

${ }^{66}$ BCA, Kurum: 30-10-0-0 Yer Bilgisi: 101 Dosya Eki: 653 Sıra No: 9, Belge Tarihi: 1924.; Anadolu Ajansının geçtiği haberlere göre Yunan adalarından ülkeye kaçak yolla giren işçiler yabancı işletmelerde çalışmaktadırlar.

${ }^{67}$ Resmi Gazete ,16.06.1932, Say1:2126.

${ }^{68}$ Kurt, a.g.m, 256-258.

69 Donald Quataert, “19. Yüzyıla Genel Bakış, Islahatlar Devri 1812-1914”, Osmanlı İmparatorluğu'nun Ekonomik ve Sosyal Tarihi, Cilt 2, Eren Yayınevi, İstanbul, 2005, s.1011.
} 
sürdürülmüştür ${ }^{70}$. $\mathrm{Bu}$ nedenlerden dolayı mensucat sanayisinde uzman işgücü oluşamamıştır.

Mensucat makinelerinin, Rus yapımı olması ve fabrika projelerinin Sovyet Rusya'da hazırlanması, Rus uzmanların, Anadolu'nun değişik bölgelerinde açılan fabrikaların ana unsuru haline getirmiştir. Kayseri, Koyna, Nazilli gibi şehirlerde açılan mensucat fabrikalarında çok sayıda yabancı iş gücü çalışmasına rağmen Rus uzmanların ayrı bir önemi olmuştur. Makinelerin yedek parçaları ve periyodik bakımları için gerekli donanımlar Sovyet Rusya'dan getirilmiştir ${ }^{71}$. Bunun yanında fabrikaların inşaatı için gerekli donananım ve inşaatçılarda Sovyet Rusya'dan getirilmesi farklı alanlardaki iş gücünün Anadolu'da aktif çalışmasına neden olmuştur. Fabrika'nın projesinde, inşaatında, tefrişatında ve işletilmesinde ana işgücü Rus uzmanlar olmuştur. Fabrikaların inşaatları çok hızlı bir şekilde tamamlanıp faaliyete geçmesi, yaşadığ 1 topraklardan çok uzakta çalışmak zorunda kalan Rus mühendislerin başarısıdır ${ }^{72}$.

İşletmelerde teknik usta, teknik mühendisi, mimar, kimyager ve mensucat üretimi alanında çeşitli uzman işgücü istihdam edilmiştir ${ }^{73}$. Bu uzmanlardan birçoğu ailesi ile fabrika lojmanlarında yaşamıştır ${ }^{74}$. Gerekli durumlarda uzmanların çalışma süreleri, yine Cumhurbaşkanlığ 1 Kararnamesi ile uzatılmıştır ${ }^{75}$. Çalışma izinleri, bazen bir yılla sınırlanırken bazen üç yılı kadar olmuştur ${ }^{76}$. II. Dünya Savaşı yılları dâhil olmak üzere çok sayıda Rus uzmanın Sümerbank fabrikalarında çalışması, üretime verilen değerin bir göstergesi olmuştur ${ }^{77}$. Bu yapı Türk işçilerin askerlik tecil işlemlerine de yansımıştır. Üretimin aksamaması için savaş yılları da olsa işçilerin askerlik tecillerine önem verilmiştir ${ }^{78}$.

Rusya'dan gelenler yabancı işgücü, fabrikaların inşaatında ve tefrişatını bitirdikten sonra görevlerini üretim süreci için gelen uzmanlara bırakmışlardır. Ayrıca fabrikalarda işçilerin teknik eğitimi için okullar açılmıştır. Okullarda metot dersleri,

\footnotetext{
70 Gülşah Yılmaz, “18. Ve 19. Yüzyılda Osmanlı İmparatorluğu'nda Yerel Tekstil Üretiminden Sanayileşmeye Geçiş", Basılmamış Yüksek Lisans Tezi, Marmara Üniversitesi Güzel Sanatlar Enstitüsü Tekstil Anasanat Dalı İstanbul, 2015, s.100-103.

${ }^{71}$ BCA, Kurum: 30-18-1-2 / Kararlar Daire Başkanlığı (1928- ), Yer Bilgisi: 62 - 12 - 5, Dosya Ek: 257-148, Belge Tarihi: 12.02 .1936 .

7216 Eylül 1935 tarihinde Kayseri Bez Fabrikasının açılış töreninde, Sovyet işçileri ve teknisyenleri adına konuşan Mühendis Kordief, Mimar Sinan Üniversitesi Sinema Televizyon Merkezi Arşivi Görüntü, İstanbul, Kayseri, 1935.

73 Mehmet Ablas; 1923 doğumlu 1938-1941 yılları arası Nazilli Basma Fabrikasında çırak olarak görevli, 1947-1976 İzmir Şark Sanayi Fabrikasında işçi daha sonra usta olarak görevli; 25 Temmuz 2009 kendisiyle yapılan röportaj - 16 Eylül 1935 tarihli Sümerbank Bez Fabrikasının açılış videosu

${ }_{74}$ Nurettin Filiz; 1921 doğumlu ilk önce Nazilli Basma Fabrikası inşaatında, daha sonrada aynı fabrikada işçi ve ustabaşı olarak 1937-1966 yılları arası görev yapmıştır. 26 Aralık 2008 yılında ölümünden sonra 2 Eylül 2009 oğlu Ramazan Haluk Filiz ile yapılan röportaj.

${ }^{75}$ BCA, Kurum: 30-18-1-2 / Kararlar Daire Başkanlığı (1928- ), Yer Bilgisi: 92 - 96 - 6, Dosya Ek: - Belge Tarihi: 28.09.1940.

${ }^{76}$ Ablas, Filiz, a.g.r.

77 Ablas, Filiz, a.g.r.

${ }^{78}$ BCA, Kurum: 30-18-1-2, Yer Bilgisi: 116-29-18. Dosya Eki: 10-350 Say1: 3/7386, Belge Tarihi: 05.05.1948.
} 
Sovyet Rusya'nın ZİT Enstitüsü'nün müfredatı uygulanmıştır ${ }^{79}$. Üretim sağlıklı bir şekilde yapılabilmesi ve kalitesinin devamlılığı için planlamalarda Rus işgücünün önemli katkısı vardır. Ayrıca üretimde kullanıla makinelerin bakım ve tamiratının doğrudan yerli ustalar tarafından yapılması için eğitimler verilmiştir. Özellikle dokuma makinelerin 1000 yakın parçası olması, bakım ve tamiratın için eğitimlerin çok zor olmasına neden olmuştur ${ }^{80}$. Bu dönemde Türk ve yabancı işgücünün işyerinde lisan sorunu yaşamaması için tercümanlar aynı işçiler gibi fabrikalarda mesai yapmışlardır ${ }^{81}$.

\section{Sonuç}

XIX. yüzyılda bilimsel bilginin, üretim unsurları üzerindeki etkisi sonucunda fabrikayalar, Avrupa şehirlerinin bir simgesi haline gelmiştir. Buna karşın neredeyse Avrupa kıtasının uzun süre yarısını yöneten Osmanlı Devleti'nin şehirlerinde ise birçok farklı nedenden dolayı fabrikaya dayalı üretim görülmemiştir. Geleneksel üretim sürmüş ve sanayileşmenin önemi ancak XIX. yüzyılın ortalarında anlaşılabilmiştir. Teknik okul ve üniversite eğitiminin yetersizliği, sanayi yatırımı girişimlerini bağımlı yapılmasına neden olmuştur. Osmanlı Devleti'nin son yüzyılından Türkiye'nin ilk yıllarına kadar sanayileşme amacıyla çalışmalar, Avrupa şirketlere verilen imtiyazlarla yapılmak istenmiştir. İmtiyazlı şirketler ise Anadolu topraklarını hammadde kaynağı olarak görmüş, zengin yeraltı ve yerüstü kaynakları Avrupa fabrikalarına taşımışlardır. Bu tek taraflı faydalanma şekli, Anadolu'da sanayi alt yapısının oluşmasını engellemiştir.

1929 buhranı ve yüzyıllardır süren ve fazla başarılı olamayan sanayileşme girişimleri, Türkiye'nin farklı bir iktisat politikası izlemesine neden olmuştur. 30'lu yılların başında Sovyet Rusya ile iktisadi anlaşmalar, daha önceki yıllarda yapılan anlaşmalardan çok farklı bir yapıda olmuştur. Yabancı şirketlere imtiyazlı ortaklık verilerek şirket açtırma anlayışı yerine devlet, kendi şirketini açarak fabrika kurma yoluna gitmiştir. Şirketlerin kurulması ve fabrika yapılması gelişmiş bir teknoloji alt yapısı gerektirmiştir. Bu gereksinim, Sovyet Rusya ile yapılan anlaşmalar sonucu, birçok alanda teknoloji transferi ile gerçekleşmiştir. Türkiye'nin mensucat alt yapısı Anadolu'nun birçok yeri gezilerek tespit edilip, Moskova'da Türk ve Rus uzmanlar tarafından projelendirilmiştir.

Projelerin en kritik noktalarından biri, fabrikaların kurumundan işleyişine kadar geçen sürede çok sayıda uzman işgücü gereksinimine ihtiyaç duyulmasıdır. Yabancı uzman işgücü çalıştırma, Osmanlı'da kurulan Avrupalı işletmelerin tercih ettiği bir anlayıştır. Bu anlayış yerli vasıflı işgücünün gelişmesini engellemekle kalmayıp aynı zamanda yabancı işgücü karşısındaki değerinizde azaltmıştır. Yabancı işgücü, işçi olarak adlandırılmış, yerli işgücü ise ameleye dönüşmüştür. Sovyet Rusya'da hazırlanan projelerde ise, her anlamada yerli işgücünü yetiştirme ve

\footnotetext{
${ }^{79}$ Yaşar Semiz, Güngör Toplu, "Cumhuriyet Döneminde Devlet Tarafından Kurulan İlk Sanayi Kuruluşu Kayseri Sümerbank Bez Fabrikası", Selçuk Üniversitesi Türkiyat Araştırmaları Dergisi, Nisan 2019, s. 47.

${ }^{80}$ Ablas, Filiz, a.g.r.

${ }^{81}$ Ablas, a.g.r.
} 
fabrikanın ana unsuru haline getirme anlayışı belirlenmiştir. Bu doğrultuda; Türk işgücü başta Sovyet Rusya olmak üzere farklı ülkelere eğitime gönderilmiş, yabancı ülkeden uzmanlar fabrikalarda hem çalışmak hem de işgücünü yetiştirmek için getirilmiştir. İnşaat, makine kurulumu, bakımları ve üretim sürecinde özellikle Rus işgücü aktif rol oynamıştır. İnşaatlarda işçi olarak çalışanlar, daha sonraki yıllarda Rus uzmanların verdiği eğitimlerle fabrikalarda ustabaşı olmuşlardır. Türkiye'de vasıflı işgücü yetiştirme çalışmaları gerçek anlamda başarıya kavuşmuştur.

\section{Kaynakça}

\section{I.Arşiv Kaynakları}

Türkiye Cumhuriyeti Cumhurbaşkanlığı Devlet Arşivleri Başkanlığı Cumhuriyet Arşivleri;

Kurum: 30-10-0-0 Yer Bilgisi: 101 Dosya Eki: 653 Sira No: 9, Belge Tarihi: 1924.

Kurum: 30-10-0-0/ Muamelat Genel Müdürlüğü Kutu No: 8 Dosya No: 46 Sıra No: 8 Belge Tarihi:-

Kurum: 30-10-0-0 / Muamelat Genel Müdürlüğ̈̈, Yer Bilgisi: 234 - 579 - 10, Dosya Ek: 422, Belge Tarihi: 25.06.1934.

Kurum: 30-10-0-0 / Muamelat Genel Müdürlüğü, Yer Bilgisi: 268 - 803 - 17, Dosya Ek: 440, Belge Tarihi: 11.09 .1935 .

Kurum: 30-18-1-2 / Kararlar Daire Başkanlığı (1928- ), Yer Bilgisi: 44 - 27 - 18 Dosya Ek: 243-161, Belge Tarihi: 03.05.1934

Kurum: 30-18-1-2 / Kararlar Daire Başkanlığ (1928- ), Yer Bilgisi: 69 - 82 - 3 Dosya Ek: 257-184, Belge Tarihi: 16.10.1936.

Kurum: 30-10-0-0 / Muamelat Genel Müdürlüğü, Yer Bilgisi: 200 - 362 - 16 Dosya Ek: 238, Belge Tarihi: 14.08.1935.

Kurum: 30-18-1-2 / Kararlar Daire Başkanlığı (1928- ) Yer Bilgisi: 41 - 85 - 7 Dosya Ek: 112-124 Belge Tarihi: 04.12.1933.

Kurum: 30-18-1-2 / Kararlar Daire Başkanlığı (1928- ) Yer Bilgisi: 47 - 58 - 19 Dosya Ek: 130-50 Belge Tarihi: 27.08.1934.

Kurum: 30-0-0-18 Yer Bilgisi: 001-002-114 Dosya Ek: 63-8 Belge Tarihi: 22.09.1947.

Kurum: 30-0-0-18 Yer Bilgisi: 001-002-115 Dosya Ek: 70-16 Belge Tarihi: 13.10.1947.

Kurum: 30-18-1-2 / Kararlar Daire Başkanlığı (1928- ), Yer Bilgisi: 62 - 12 - 5 Dosya Ek: 257-148, Belge Tarihi: 12.02.1936.

Kurum: 30-18-1-2 / Kararlar Daire Başkanlığı (1928- ), Yer Bilgisi: 92 - 96 - 6 Dosya Ek:-, Belge Tarihi: 28.09.1940.

Kurum: 30-18-1-2, Yer Bilgisi: 116-29-18. Dosya Eki: 10-350 Sayı: 3/7386, Belge Tarihi: 05.05.1948.

Mimar Sinan Üniversitesi Sinema Televizyon Merkezi Arşivi, 16 Eylül 1935 tarihinde Kayseri Bez Fabrikasının açılış töreninde, Sovyet işçileri ve teknisyenleri adına konuşan Mühendis Kordief, Görüntü, İstanbul, Kayseri, 16 Eylül 1935. 


\section{Resmi Yayınlar}

TBMM Zabıt Ceridesi, Cilt 32, TBMM Matbaası, Ankara, 1927.

Düstür, Cilt.8, İstanbul Evkaf Matbaası, İstanbul, 1928.

\section{Süreli Yayınlar}

Akşam Gazetesi; 11 Ağustos 1932, 11 Ağustos 1932, 18 Şubat 1934, 24 Nisan 1932, 27 Ekim 1931, 30 Nisan 1932, 7-18 Eylül 1932, 8 Mayıs 1932.

Cumhuriyet Gazetesi; 22 Mayıs 1930, 6 Haziran 1933.

Endüstri Dergisi, Nisan 1937, Sayı: 8.

Hâkimiyeti Milliye Gazetesi, 8 Eylül 1932.

Resmi Gazete; 16.06.1932, Sayı:2126, 24.05.1934, No: 2709.

Sümerbank Bülteni, Yı1:3, Sayı: 9-10.

Ulus Gazetesi; 28 Ekim 1931.

\section{Kitaplar}

Atatürk'ün Söylev ve Demeçleri, I-III, Atatürk Araştırma Merkezi, Divan Yayınları, Anakara, 2006.

Çelik, B. (2004). "Osmanlı Lonca Sistemi İçinde Yamaklık Olgusu”, Cilt: XXIII, Tarih Araştırmaları, Ankara.

Doğan, H. (2007).“Sanayinin Musikisi Nasıl Başladı Nasıl Bitti? Sümerbank Nazilli Basma Fabrikası'na Tarihsel Bir Bakış", Ege Akademik Bakış / Ege Academic Review 7 (2), İzmir.

Drake, P.W. (t.y.) " Edwin Walter Kemmerer " in Encyclopedia of Latin American History and Culture, vol. 3 .

F. Katz, L., Margo, R. A. (2014). “Technical Change and the Relative Demand for Skilled Labor", The United States in Historical Perspective, October.

Giz, A. (1968). "Islâh-1 Sanayi Komisyonu", İstanbul Sanayi Odası Dergisi, Sayı:33, İstanbul.

Giz, A. (1969). "İstanbul'da İlk Sanayi Mektebinin Kuruluşu”, İstanbul Sanayi Odası Dergisi, Sayı:35, İstanbul.

Günalan, R. (2016). “Tanzimat Sonrasında Osmanlı Devletinde Yabancı Şirketler Tarafından Yürütülen İş ve İşlemlerinde Türkçenin Kullanımı Meselesi", Avrasya İncelemeleri Dergisi, V/2, İstanbul.

İmamoğlu, H. V. (2018). Osmanlı Son Dönemi ve Büyük Güçler, İstanbul: Kriter Yayınevi.

Kanca, H. (2013). “XIX. Yüzyılın İkinci Yarısında Uluslararası Osmanlı Fuarı: 1863 - Sergi-i Umumi-i Osmani", Muhasebe ve Finans Tarihi Araştırmaları Dergisi, sayı:5, İstanbul.

Karayaman, M. (2010). "Osmanlı Devletinde Şeker Fabrikası Kurma Teşebbüsleri”, Tarih İncelemeleri Dergisi, Cilt: 25 Sayı: 1, İzmir.

Kodaman, B. (1980).'Tanzimat'tan 2. Meşrutiyete Kadar Sanayi Mektepleri', Türkiye'nin Sosyal ve Ekonomik Tarihi (1071- 1920), Editörler: Osman Okyar, Halil İnalcık, Ankara. 
Kurt, M. K., Kuzucu, Çakır, B., Demir, K. (2016). “19. Yüzyılda Osmanlı Sanayileşmesi Sürecinde Kurulan Devlet Fabrikaları: Bir Envanter Çalışması", Ankara Üniversitesi Osmanlı Tarihi Araştırma ve Uygulama Merkezi Dergisi, 40 /Güz, Ankara.

\section{Makaleler}

Olff, G., Achard, F. K. (1953). 1753-1821; a Contribution of the Cultural History of Sugar Medizinische Monatsschrift 7, no. 4.

Osmanlı Devleti'nin İlk İstatistik Yıllığı 1897, Cilt 5, Hazırlayan: Tevfik Gürhan, Devlet İstatistik Enstitüsü Yayınları, Ankara, 1997.

Osmanlı Sanayi 1913,1915 Yılları Arası, Cilt 4, Hazırlayan: A. Gündüz Ökçün, Devlet İstatistik Enstitüsü Yayınları, Ankara, 1997.

Ökçün, A. G. (1975). “Teşvik-i Sanayi Kanun-1 Muvakkatı,1913” Ankara Üniversitesi Siyasal Bilgiler Fakültesi, Dergisi, Cilt: 30, Ankara.

Ökçün, A. G. (1971). Türkiye İktisat Kongresi 1923-İzmir Haberler Belgeler Yorumlar, Sevinç Matbaası, Ankara.

Öztürk, N. (1990). “XIX. Yüzyılda Osmanlı İmparatorluğu'nda Sanayileşme ve 1827'de Kurulan Vakıf İplik Fabrikası", Vakıflar Dergisi, Sayı 21, İstanbul.

Pamuk, Ş. (2008). Osmanlı Ekonomisi ve Kurumları, Türkiye İş Bankası Yayınları, İstanbul.

Pamuk, Ş. (1994). Osmanlı Ekonomisinde Bağımlılık ve Büyüme, Tarih Vakfı Yurt Yayınları, Ankara.

Quataert, D. (2005). “19. Yüzyıla Genel Bakış, Islahatlar Devri 1812-1914”, Osmanlı İmparatorluğu'nun Ekonomik ve Sosyal Tarihi, Cilt 2, Eren Yayınevi, İstanbul.

Semiz, Y., Toplu, G. (2019). “Cumhuriyet Döneminde Devlet Tarafından Kurulan İlk Sanayi Kuruluşu Kayseri Sümerbank Bez Fabrikası", Selçuk Üniversitesi Türkiyat Araştırmaları Dergisi, Konya.

Şahinkaya, S. (1998). “XIX. Yüzyıl Osmanlı İmparatorluğu'nun İktisadi Yapısı: Sanayicilik ve Bankacılık Üzerinde Değinmeler", Mülkiye Dergisi, Cilt XXIII, Sayı:218, Ankara.

Şişman, A. (2004). Tanzimat Dönemi'nde Fransa'ya Gönderilen Osmanlı Öğrencileri (18391876), Türk Tarih Kurumu Yayınları, Ankara.

Tezel, Y.S. (2002). Cumhuriyet Dönemi İktisadi Tarihi (1923-1950), Tarih Vakfı Yurt yayınları, İstanbul.

Thobie, J. (1985). “Osmanlı Devletinde Yabancı Sermaye”, Tanzimat'tan Cumhuriyet'e Türkiye Ansiklopedisi, Cilt 3, İletişim Yayınları İstanbul.

Timur, T. (2001). Türk Devrim ve Sonrası, İmge Yayınları, Ankara.

Toprak, Z. (1985). "II. Meşrutiyet ve Osmanlı Sanayi", Tanzimat'tan Cumhuriyet'e Türkiye Ansiklopedisi, İstanbul.

Uzunçarşıll, İ. H. (1959). Osmanlı Tarihi, Cilt 4, TTK, Ankara.

Yıldırım, M. A. (2012). “II. Meşrutiyet Devrinde Vilayet Sanayi Mekteplerini Yeniden Yapılandırma Girişimleri: Vilâyât Sanayi Mektepleri Tertibatı", Tarih Araştırmaları Dergisi Cilt: 31 Sayı: 52, Ankara. 


\section{Sözlü Tarih Görüşmeleri}

Mehmet Ablas; 1923 doğumlu 1938-1941 yılları arası Nazilli Basma Fabrikasında çırak olarak görevli, 1947-1976 İzmir Şark Sanayi Fabrikasında işçi daha sonra usta olarak görevli; 25 Temmuz 2009 kendisiyle yapılan röportaj.

Nurettin Filiz; 1921 doğumlu ilk önce Nazilli Basma Fabrikası inşaatında, daha sonrada aynı fabrikada işçi ve ustabaşı olarak 1937-1966 yılları arası görev yapmıştır. 26 Aralık 2008 yılında ölümünden sonra 2 Eylül 2009 oğlu Ramazan Haluk Filiz ile yapılan röportaj.

\section{Basılmamış Tezler}

Bigat, B. (2017). Kuruluşu Ve İlk Yıllarında Nazilli Sümerbank Basma Fabrikası, Adnan Menderes Üniversitesi Sosyal Bilimler Enstitüsü Tarih Anabilim Dalı Basılmamış Yüksek Lisans Tezi, Aydın.

Yılmaz, G. (2015). 18. Ve 19. Yüzyılda Osmanlı İmparatorluğu'nda Yerel Tekstil Üretiminden Sanayileşmeye Geçiş, Basılmamış Yüksek Lisans Tezi, Marmara Üniversitesi Güzel Sanatlar Enstitüsü Tekstil Anasanat Dalı, İstanbul. 